\title{
"Capital structure and performance of Middle East and North Africa (MENA) banks: an assessment of credit rating"
}

AUTHORS

ARTICLE INFO

DOI

RELEASED ON

JOURNAL

FOUNDER
Ahmed A. El-Masry

Ahmed A. El-Masry (2016). Capital structure and performance of Middle East and North Africa (MENA) banks: an assessment of credit rating. Banks and Bank Systems, 11(1), 77-91. doi:10.21511/bbs.11(1).2016.09

http://dx.doi.org/10.21511/bbs.11(1).2016.09

Monday, 25 April 2016

"Banks and Bank Systems"

LLC "Consulting Publishing Company "Business Perspectives"

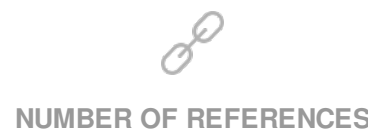

0
NUMBER OF FIGURES

0

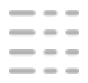

NUMBER OF TABLES

0

(C) The author(s) 2022. This publication is an open access article. 
Ahmed A. El-Masry (UK, Egypt)

\title{
Capital structure and performance of Middle East and North Africa (MENA) banks: an assessment of credit rating
}

\begin{abstract}
The firm's credit rating is an important communication tool and previous research has shown that many companies consider it important in capital structure decisions. This study examines the determinants of capital structure in MENA banks. In addition, it investigates the determinants of credit rating. Further, the impact of credit rating and capital structure on banks' performance is examined. Therefore, this study is an attempt to answer the following questions: 1) what are the main determinants of capital structure? 2) how does credit rating affect capital structure? 3) what are the main determinants of credit rating? and 4) what is the effect of capital structure and credit rating on bank performance? The sample covers 169 banks and is divided into two sub-samples: rated (79) and non-rated banks (90). The results indicate that credit rating directly affects the capital structure decisions as rated banks use more debts than non-rated banks. Banks' performance is positively associated with credit rating and negatively with the capital structure. This study has an implication on investors in their decisions to invest in the banking industry. It also helpful for policy makers to understand how bank's capital structure behaves so they could take it into consideration when issuing new regulations such as Basel.
\end{abstract}

Keywords: capital structure, credit rating, profitability, MENA banks.

JEL Classification: C23, G21, G32, N25.

\section{Introduction}

Capital structure is one of the most intriguing corporate issues and continues to motivate top management and academics to determine the optimal combination of debt and equity that will maximize firm value and increase investors' pecuniary benefits. Although there has been an extensive empirical research on capital structure, to date there is no unanimous consensus regarding the best mix of debt and equity (Dasilas and Papasyriopoulos, 2015). Academic interest in capital structure dates back to the seminal work of Modigliani and Miller (1958), who proposed that under "perfect" capital markets a firm's value is unaffected by its capital structure. However, the existence of several "imperfections" in the real world (such as adverse selection, moral hazard, agency conflicts, market frictions and taxes) creates obstacles to a firm's access to external finance (Vermoesen et al., 2013). Credit rating is an increasingly important component of finance theory and practice (Kisgen, 2009). Moreover, Jucá et al. (2012) investigate the banks' capital structure using a sample of U.S. and Brazilian banks. Their findings are in agreement with the work done by Gropp and Heider (2010) in that the standard determinants of capital structure are of first order in explaining the capital structure. They found that the majority of the determinants they hypothesized were significant in explaining the capital structure of bank. These are asset risk, deposits, size, growth, tangibility and dividends. The previous literature that examines the nature and the determinants of corporate structure in Western countries is very rich, however, a limited

(C) Ahmed A. El-Masry, 2016.

Ahmed A. El-Masry, Ph.D., Associate Professor of Finance, Plymouth Business School, UK \& Mansoura University, Egypt. number of studies have examined the nature and determinants of capital structure of banks in the MENA region. In addition, most of the empirical studies that examine the capital structure decision focused only on some of the commonly used variables such as profitability, asset structure, size, growth opportunities, liquidity, effective tax rate, inflation rate, and operating risk.

Although there has been an extensive prior research examining the determinants of capital structure decisions, there is a limited research explaining credit rating as one of these determinants. Kisgen (2006) found that credit rating directly affects capital structure decisions on the US market in the period from 1986 to 2001. In his study, he found that companies near a credit rating upgrade or downgrade issued less debt relative to net equity as a percentage of total assets than firms not near a credit rating change, a finding which is inconsistent with the traditional capital structure theories, as their predictions do not include the impact of credit rating on capital structure decisions. A similar study performed by Michelsen and Klein (2011) on an international sample in the period of 1990-2008 found further evidence of credit rating impact on firms' financial gearing decisions. More recently, Drobetz and Heller (2014) used a sample of listed US firms and one of listed and non-listed German firms in order to test the credit rating- capital structure hypothesis. The results from the U.S. sample corroborated Kisgen's (2006, 2009) credit rating capital structure hypothesis, suggesting that there exists a minimum target rating and that financial distress concerns are only of secondary importance. What the previous studies on the topic have in common is that they largely focus on U.S. data due to the extensive use of corporate bonds as well as 
credit rating in the U.S. capital markets. However, a few empirical studies have examined the effect of credit rating on capital structure decisions, especially in the developing countries, and more specifically, in MENA area. Credit rating has gained an increasingly relevant role in the past decades. In financial markets, its importance has been acknowledged since its beginning in the 19th century, as the primary objective of credit rating is to decrease information asymmetry by providing the issuer's creditworthiness to the investors. The role and the effect of credit rating increase steadily. Credit rating affects the cost of firm's debt financing as lower credit rating leads to an increase in the cost of debt. There is an association between the capital requirement of the bank with the credit rating issued for the banks by a credit rating agency; the higher the bank's credit rating, the lower the capital requirement. Credit rating is also used to deal with the default risk of counterparty. Some contracts require parties engaged in a contract to have specific credit rating, and if the credit rating of one party falls below a specific rating, the other party can withdraw from the contract. The empirical studies also confirm the significance of credit rating. Graham and Harvey (2001) find that "the most important factors affecting debt policy are maintaining financial flexibility and having a good credit rating." Gray et al. (2006) point out that "credit rating is of great practical importance, as they impact the firm's cost of debt, its financial structure, and even its ability to continue trading". Servaes and Tufano (2006) confirm that credit rating is far more important in capital structure decisions than suggested by the theory. From their study, survey respondents indicate that they are the single most important factor in firm's decisions.

The role of credit rating agencies has increased in the last years. Asgharian (2005) argues that the development in the credit rating agencies is related to two important factors, those factors are disintermediation and globalization. Credit rating agencies (CRAs) play two important roles: valuation role and facilitate contracting (Frost, 2006). With regard to the role of valuation, CRAs act as screening agents. Rates provided by the CRAs also are considered as covenants, so they can be used as efficient credit quality benchmark. Credit rating facilitates the contracting process between the company and the other party (Frost, 2006). The credit rating analysts start their work by visiting the company and analyzing both the financial and non-financial aspects of the company. The financial aspects include, for example: leverage, profitability, liquidity, size, and growth opportunities, and this will be explained in more details in the analysis of credit rating determinants. The non-financial aspects include, for exam- ple: industry risk, country risk, company's competitive position, management quality, company reputation, and the degree of reliance on specific suppliers and customers. Credit rating gives a signal for both public information and non-public information. CRAs reduce information asymmetries between the managers of the company and investors. According to Boot et al. (2003), "rating agencies could be seen as information-processing agencies that may speed up the dissemination of information to financial markets". And, according to Champsaur (2005), "credit rating promote market efficiency by allowing issuers to signal their creditworthiness to lender, thus, helping lenders to allocate capital to creditworthy borrowers". Company with a high credit rating will access the capital market easily and, in the same time, can issue more debt. High credit rating provides the company with the legitimacy to issue more debt than those companies with lower credit rating. Asgharian (2005) identifies the motives for companies to get higher credit rating 1) high credit rating increases the ability of the company to issue debt and facilitates its access to the capital market, 2) new companies can make the best use of high credit rating through building up their market reputation, and 3) lower cost of fund as credit rating can be seen as a competitive advantage that distinguishes one company from another company, especially, in industries characterized by a limited number of competing companies. Several studies have found evidence to support both the trade-off and pecking order theories (e.g., Brounen et al., 2005; Fama and French, 2002; ShyamSunders and Myers, 1999), but, due to the complex nature of the field of capital structure, these theories do not capture all relevant factors that may affect a firm's debt-equity choice, and there is, yet, no universally accepted theory explaining the capital structure decision of firms (Adeyemi and Oboh, 2011; Kronwald, 2009). Moreover, Dasilas and Papasyriopoulos (2015) claim that firm-specific determinants such as size, profitability, asset structure and growth opportunities are also significant determinants of leverage.

The main theories that explain the capital structure decisions are trade-off and pecking order theories. In the trade-off theory, capital structure decisions depend on the costs and benefits associated with debt financing, or, to put it another way, a firm's optimal leverage is determined by a trade-off of the costs and benefits of holding debt (Myers, 1984). The theory holds that a firm, in order to achieve an optimal capital structure that maximizes the total market value, seeks debt levels that balance the value of interest tax shields against the various costs of bankruptcy or financial distress. The trade-off 
theory implies that the benefits of holding debt (e.g., the tax shield) will cause firms of higher quality (rating), and, thereby, lower risk of bankruptcy, to issue more debt relative to firms of lower quality. Under the trade-off theory, the firm compares the advantages with the disadvantages of using debt relative to equity and the optimal point is the point that balances both at the margin. Using debt leads to tax deductibility that motivates the firm to use more debt relative to equity. But the extent to which the firm can benefit from this tax deductibility will depend on the ability of the firm to produce taxable income. In addition, there are two types of costs of using debt: financial distress (bankruptcy costs) and agency costs. First: financial distress costs are divided into direct costs and indirect costs. Direct costs are considered out-of-pocket cash expenses and include the following: fees of lawyers, administrative fees and value of managerial time spent in administering the bankruptcy. In other words, the direct costs of bankruptcy include the legal, administrative and reorganizing costs that result from bankruptcy (Haugent and Senbet, 1978). The indirect costs are not considered as cash expenses. They include damage of the firm reputation that leads to the loss of skilled employees and, also, include the diversion of management time while bankruptcy is underway (Titman, 1984). Palata (2003) argues that the indirect costs of bankruptcy include: the impaired ability to conduct business and tendency to underinvestment. Second: agency costs that arise as a result of the conflict of interest between the shareholders and debtors. Kisgen (2006) argues that there are costs and benefits associated with the different levels of credit rating. Those costs and benefits will differ from one firm to another according to the rate provided to each one. Those costs and benefits associated with the different credit rating should be in the mind of managers when they are making a decision about the level of debt they will issue. Managers should balance the costs and benefits of different credit rating against the costs and benefits of the traditional trade-off theory. The optimal level of debt that will maximize the firm's value under the traditional trade-off theory will differ from the optimal level of debt if the benefits and costs of the different levels of credit rating are considered. Kisgen (2006) indicates that different credit rating will have an effect on the firm debt ratio and, in turn, on the maximum value the firm can reach. Kisgen (2006) tests the effect of the change in the credit rating on the traditional trade of theory and argues that "firms near an upgrade or a downgrade may be less willing to increase their debt levels, even if they are currently below their target levels. However, firms far away from an upgrade or downgrade will be in better position to increase their debt levels if they are below their target, since they will be less concerned about a change in rating".

In contrast with the trade-off theory, here the benefits related to tax shields and the costs of financial distress are of second order (Shyam-Sunder and Myers, 1999; Myers and Majluf, 1988). Furthermore, Shyam-Sunder and Myers (1999) stress that, in the pecking order model, the optimal capital structure does not determine the level of debt; unlike the trade-off theory, there is no optimal debt ratio. Firms will issue more or less debt depending on access to internal funds when financing an investment. Leverage will function as a short-term offset to finance a predicted deficit. Thus, when investments exceed internal capital, firms will increase the amount of debt, and vice versa (Frank and Goyal, 2003). The pecking order theory states that there is a hierarchy for the sources of financing firm's projects. Projects should be financed, first, by internal funds (retained earnings), when internal funds are exhausted the firm can use debt, and finally when the firm reaches its debt capacity, it can, then, issue equity. The reason beyond this hierarchy is the asymmetric information between managers and outside investors (Myers, 1984; Myers and Majluf, 1984). Fama and French (2000) determine the logic beyond the pecking order theory as follows. Managers may issue risky securities when those securities are overpriced. But when new securities issue are announced, investors having inferior information about the value of the firm's assets can misprice those securities. Consequently, the new securities will be underpriced in the market. Managers, in turn, will pass projects with a positive net present value which will be financed by issuing equity, because managers work to achieve the maximum benefits for shareholders. In order to avoid this problem, managers prefer to finance projects, first, by retained earnings where there is no asymmetric information, followed by debt issue and, finally, with equity. Kisgen (2006) argues that "contrary to the implications of the pecking order theory, in some cases, firms that are near an upgrade may choose to issue equity instead of debt in order to obtain the benefits of higher rating, and firms that are near a downgrade may avoid issuing debt to prevent the extra costs that result from a downgrade". So firms will not be restricted to finance their projects according to the sequence of the pecking order theory. Kisgen (2006) tests the effect of the credit rating changes on the pecking order theory and finds that credit rating has a significant effect on the capital structure decision. Both theories, trade-off and pecking order, try to explain the capital structure choice through a set of factors. Which factors are really relevant in a firm's funding choice is one key aspect for the topic. There are 
many papers that tackle this issue: what are the determinants of capital structure choice? The identification of these determinants may not be the most challenging part of the process, as many of them have an intuitive understanding. Many factors are difficult to define in an econometric model, so proxies must be used. If these proxy indicators are not constructed carefully, then, the results might turn out skewed. These determinants are 1) the tax benefits, 2) bankruptcy and financial distress costs and 3) information asymmetry. Different empirical studies address the relevance of the referred determinants, using a variety of measure indicators such as size, profitability, growth, industry classification, etc. These studies do not lead to the same unique conclusion as regards which capital structure theory is the most adaptable to the real world. That is, there is not yet a theory that explains fully the capital structure decisions of all firms.

The study examines the impact of credit rating on the capital structure decisions of 169 MENA banks by running two models: the first model includes the determinants of capital structure most commonly used in the literature and the second model includes all the variables used in the first model plus credit rating as a dummy variable. The study also investigates the determinants of credit rating. Finally, the study examines the impact of both credit rating and capital structure decision on the banks' performance. Therefore, this study is an attempt to answer the following questions: 1) what are the main determinants of capital structure? 2) how does credit rating affect capital structure? 3), what are the main determinants of credit rating? and 4) what is the effect of capital structure and credit rating on bank performance? The sample includes those banks that locate in ten MENA countries, namely: Bahrain, Egypt, Jordan, Kuwait, Lebanon, Oman, Qatar, Saudi Arabia, United Arab Emirates, and Yemen over the 2014 period and data are collected from the BankScope database. All banks that do not have information in the 2014 were excluded. Also, all banks with any missing observations for any variable during the sample period were dropped. After excluding all the missing observations, the sample size will be 169 banks. The sampled banks are divided into two basic groups: the first one includes banks with credit rating (79 banks), the second one includes banks without any credit rating (90 banks). From Table 1, it appears that banks with credit rating represent $47 \%$ of the total No. of banks.

Table 1. The sample

\begin{tabular}{|l|c|c|c|}
\hline \multicolumn{1}{|c|}{ Country } & Banks with credit rating & Banks without credit rating & Total banks \\
\hline UAE & 22 & 7 & 33 \\
\hline Egypt & 11 & 22 & 18 \\
\hline Bahrain & 10 & 8 & 15 \\
\hline Jordan & 9 & 6 & 11 \\
\hline Saudi Arabia & 8 & 3 & 26 \\
\hline Qatar & 7 & 4 & 14 \\
\hline Lebanon & 4 & 22 & 5 \\
\hline Kuwait & 4 & 10 & 7 \\
\hline Oman & 2 & 3 & 169 \\
\hline Yemen & 2 & 5 & \\
\hline Total & 79 & 90 & \\
\hline
\end{tabular}

Source: BankScope.

The results indicate that credit rating has an influential effect on the capital structure decision; banks with credit rating use more debt than banks without any credit rating. The results also reveal that CRs do not rely heavily on quantitative factors in their rating, only the size and the country rating have the most pronounced effect on credit rating. Finally, the results imply that banks' profitability correlates positively with credit rating while correlates negatively with the debt ratio. To my knowledge, no previous studies investigating the relationship between credit rating and capital structure have focused empirically solely on the MENA banks, rendering this present study unique. This study is organized as follows. Section 1 reviews the relevant literature of the determinants of capital structure. Section 2 presents for the study hypotheses and models. Section 3 reports the main the results of the three themes of this study which are the determinants of capital structure, the determinants of credit rating and the relationship between capital structure, credit rating and bank performance measured by profitability. Final Section concludes the study.

\section{Literature review}

\subsection{The determinants of capital structure.}

1.1.1. Profitability. The relationship between profitability and capital structure can be viewed from two points of view. First: trade-off theory framework suggests that profitable firms should borrow more to take tax advantage. Modigliani and Miller (1963) argue that companies may use more debt relative to 
equity to make the best use of the tax deductibility of interest payments, so profitable firms use more debt to obtain tax shields. This positive relationship is supported by the Bowen et al. (1982), Dammon and Senbet (1988) and Givoly et al. (1992). Second: pecking order theory views that the firm's need to borrow either long-term or short-term is decreased as the profitability of the firm increases, so there is a negative relationship between profitability and leverage. Myers (1984) and Myers and Majluf (1984) point out that, according to the pecking order theory, retained earnings are considered the first preference for financing firms' investment followed by debt financing and last comes new equity issue, where the cost of issuing new equity is high because of the transaction costs. Consequently, profitability allows firms to use retained earnings rather than external finance. This theoretical negative relation between profitability and leverage is supported by the empirical results of Toy et al. (1974), Kester (1986), Titman and Wessels (1988), Bennett and Donnely (1993), Rajan and Zingales (1995), Booth et al. (2001), Bevan and Danbolt (2002), Michaelas et al. (1999), Fama and French (2002), Bevan and Danbolt (2004), Sogorb-Mira (2005), LopezGracia and Sogorb-Mira (2008), Daskalakis and Psillaki (2008), Psillaki and Daskalakis (2009), Degryse et al. (2012), Palacin-Sanchez et al. (2013) and Mateev et al. (2013).

1.1.2. Asset structure (tangibility). Asset structure is the ratio of fixed assets to total assets and it is used as a proxy for collateral. When a firm requires a loan from a lender, the lender wants to reduce the risk that he carries, so he may require collateral to save himself. By increasing collateral, the firm's ability to use debt will increase, the lower the financing costs of the firm, the lower the costs of financial distress in case of bankruptcy, and also reducing the agency problems. The financial distress and agency theory suggests that there is a positive relation between leverage and collateral. The empirical results of Bradley et al. (1984), Titman and Wessels (1988), Rajan and Zingales, (1995), Kremp et al. (1999), and Frank and Goyal (2003) support the positive relation between asset structure and leverage. Booth et al. (2001) and Nivorozhkin (2002), when examining the capital structure in the developing countries, found a negative relation between asset structure and leverage. Chittenden et al. (1996) found a positive relation between asset structure and long-term forms of debt and negative relation with short-term debt. De Jong (1999), Michaelas et al. (1999), Bevan and Danbolt (2004), Sogorb-Mira (2005), Degryse et al. (2012) and Mateev et al. (2013) all confirm the positive relationship between tangible assets and leverage. Degryse et al. (2012) and Mateev et al. (2013) assert that asset structure may affect short-term and long-term debt differently.
1.1.3. Non-debt tax shield. Most of the empirical studies examine the relationship between capital structure and non-debt tax shield. DeAngelo and Masulis (1980) extended Miller's (1977) study of non-debt tax shields and found that, apart from interest expenses, depreciation and investment tax credits (non-debt tax shields) could also provide tax benefits to firms. They also argued that a firm with larger non-debt tax shields is expected to use a smaller amount of debt. In his empirical work, Wald (1999) employed the ratio of depreciation expense to total assets and found a negative correlation between leverage and non-debt tax shields. Empirical tests of the non-debt tax shield effect on debt policy are mixed. For example, Givoly et al. (1992), Graham (1996) and Lopez-Gracia and Sogorb-Mira (2008) found a negative relationship between the firm's debt and NDTS supporting DeAngelo and Masulis' (1980) substitutability hypothesis, that is, non-debt tax deductions substitute for the tax shield benefits of debt. Titman and Wessels (1988) findings show that there is a negative relationship between the non-debt tax shield and the leverage. Bradley et al. (1984), Bathala et al. (1994), Jiraporn and Gleason (2007) and Dasilas and Papasyriopoulos (2015) found a positive relationship between leverage and non-debt tax shield. Finally, Degryse et al. (2012) found a negative (positive) relationship between long-term debt (short-term debt) and non-debt tax shield using a sample of Dutch SMEs. On the other hand Ozkan (2001) argues that this proxy might not represent the non-debt tax shield and that firms with higher deprecation ratios would have lower growth opportunities and, therefore, he suggested a positive relationship.

1.1.4. Liquidity. According to Ozkan (2001), liquidity ratio may have unclear impact on leverage. Positive relation may exist between liquidity and leverage because more liquidity increases the firm's ability to meet its short-term financial obligations when they become due. Negative relation may also exist; the more liquid is the firm, the more incentives to use these assets to finance its investments instead of using debt to finance the investment. Eldomiaty (2007) suggests that there is a negative relationship between leverage and liquidity proxy. Sbeti (2010), Nikolaos et al. (2007) and Ozkan (2001) find a negative relationship between liquidity and leverage. Furthermore, since the sample we examine in this study is banks liquidity, it is crucial. Liquidity is measured by using the banking liquidity ratio of net loans to total assets.

1.1.5. Size. Rajan and Zingales (1995) point out that the effect of size on leverage is unclear. The trade-off theory argues a positive relation between the firm size and leverage because large firms are more diversified and this diversification reduces the operating risk. Since the probability of bankruptcy for large firms is small and the bankruptcy cost is low, this encourages 
large firms to use more debt. Large firms have lower agency costs than smaller firms (Chung, 1993). They may be able to make the best use of economies of scale in issuing long- term debt and can exert bargaining power over creditors (Nguyen and Ramachandran, 2006). Large firms may be able to take advantage of the tax shield, so they require more debt (Deesomsak, Paudyal and Pescetto, 2004). They are easier to access the credit market and borrow at more favorable interest rates (Ferri and Jones, 1979). Large firms do not suffer from information asymmetries with lenders (Cassar and Holmes, 2003). The vast majority of studies find a positive relationship between firm size and leverage both for large firms and SMEs (see Van Dijk, 1997; De Jong, 1999; Fama and French, 2002; Michaelas et al., 1999; Bevan and Danbolt, 2004; Sogorb-Mira, 2005; Hall et al., 2004; Lopez-Gracia and Sogorb-Mira, 2008; Psillaki and Daskalakis, 2009; Degryse et al., 2012; Palacin-Sanchez et al., 2013: Dasilas and Papasyriopoulos, 2015). Akhtar and Oliver (2009) find a similar relationship for both multinational and domestic Japanese firms. Furthermore, studies in the emerging market found a similar results to the previous ones such as Huang and Song (2006), Booth et al. (2001) and Rajan and Zingales (1995) all support a positive relationship. On the other hand, the pecking order theory postulates a negative relation between the firm's size and leverage. Small firms prefer to use short-term debt as they pay more than large firms to obtain equity or long-term debt. Small firms tend to use a large amount of short-term debt because of the lower costs associated with this type of financing (Titman and Wessels, 1988). Another reason is related to the cost of information gathering and monitoring, where it will be difficult for the lender to generate the required information about large firms that spread their transactions in many areas, but it is easy to collect comprehensive information on small firms, as a result, small firms tend to use more bank debt (Ojeh and Manrique, 2005). This inverse relation is consistent with the empirical studies of Kester (1986), Kremp et al. (1999), and Titman and Wessel (1988) while Bevan and Danbolt (2002) and Dasilas and Papasyriopoulos (2015) found that the relation between size and debt will depend on the proxy used to measure the leverage (short-term debt, long-term debt and total debt). Size of the bank will be measured as the natural logarithm of total assets, same measure used by Homaifar et al. (1994).

1.1.6. Inflation. During inflationary periods the real cost of debt decreases. This positive relation is suggested by Jaffe (1978), DeAngelo and Masulis (1980), and Modigliani (1982). Inflation rate is measured by using the consumer price index for each country during the sample period of 2004.
1.1.7. Operating risk. Frank and Goyal (2009) argue that companies with volatile stock are expected to be riskier due to the fact that prices reflect the business risk of the bank. Both the pecking order theory and the trade-off theory predict a negative relationship between the risk and leverage. Higher risk means that the probability of paying their debt is less and, hence, lenders will ask for higher return. Some studies such as Bradley et al. (1984), Titman and Wessels (1988), Walsh and Ryan (1997), Kremp et al. (1999), and Booth et al. (2001) suggest that operating risk is inversely related to the use of debt, since the financial distress increase as a result of the unstable earnings. Also firms' accumulation of cash during periods of stable earnings increases, in order to be able to operate in periods of low earnings, and meet the unexpected conditions (Gaud et al., 2005). Operating risk will be measured by using the standard deviation of total operating income for the bank of the last three years divided by the mean of operating income for those three years.

1.1.8. Growth opportunities. The relationship between growth opportunities and the leverage is ambiguous. Negative relationship is expected according to agency theory, where growth opportunities reduce the liquidation value (collateral asset), since those growth opportunities are intangible. Consequently, the firm ability to use debt is limited. However, the pecking order theory postulates that there is a positive relation, where in the growth stage, firms require more money to fund their investment, as a result, highly growing firms may tend to use more debt to finance their investment. The contradiction is not only between different theories, but also among different empirical studies (Myers, 1977; Titman and Wessels, 1988; Rajan and Zingales, 1995; Barclay and Smith, 1996; and Bevan and Danbolt, 2002) found a negative relation between growth opportunities and debt. The studies of Graham and Harvey (2001), Fama and French (2002), Jiraporn and Gleason (2007) and LopezGracia and Sogorb-Mira (2008) also verify the negative relationship between growth opportunities and leverage. On the other hand, a positive relation is consistent with empirical studies of Myers and Majluf (1984) and Michaelas et al. (1999). Moreover, firms that grow are more likely to experience a strain on their internal funds and more likely to resort to external finance, preferably, debt (Mateev et al. 2013). Michaelas et al. (1999), Sogorb-Mira (2005), Degryse et al. (2012), Palacin-Sanchez et al. (2013) and Dasilas and Papasyriopoulos (2015) confirm that growth opportunities have a positive impact on leverage of Greek listed firms. In addition, Chen (2004) also finds a positive relationship in a sample of Chinese companies. Furthermore, Al-Sakran (2001) finds that the effect of growth on leverage is 
negative for certain sectors and insignificant for others. This could be interpreted as that companies in different industries have different relationship between leverage and growth. However, Chittenden et al. (1996), Jordan et al. (1998), and Ozkan (2000) found mixed evidence, where the relation will depend on the measurement of debt either by total debt or short-term debt or long-term debt. This is supported by the results of Bevan and Danbolt (2002) which indicate that growth opportunities are positively related to short-term debt and negatively to long-term debt. Growth opportunities are measured as the percentage change in total assets (Titman and Wessels, 1988).

\subsection{The determinants of credit rating.}

1.2.1. Leverage. Firms finance their operations with liabilities and equity. In general, as you increase the level of debt in the capital structure of an entity, other variables hold constant, the company becomes riskier. Therefore, we expect a negative relationship between credit rating and debt level. According to Bouzouita and Young (1998), a high level of leverage increases the probability of default and the adverse variations in underwriting and/or economic conditions may, therefore, affect the rating. Shiu and Chiang (2008) add that a firm with high debt tends to have a high financial uncertainty and, consequently, high risk of insolvency. Cantor and Packer (1997), Blum, Lim and Mackinlay (1998), Adams et al. (2003), Gray et al. (2006) and Dasilas and Papasyriopoulos (2015) argue that high level of leverage may be associated with greater uncertainty, consequently, increasing the probability of bankruptcy, which results in decreasing the likelihood that firms will be rated. On the other hand, Kemper (2011) finding shows that credit rating is not a first order concern of capital structure decisions, and that the model does not hold through the different classes of credit rating. However, Shen et al. (2012) find that the effects between credit rating on capital structure persist significantly in the context of trade-off and pecking order theory.

1.2.2. Profitability. Generally, a profitable firm has a greater ability to generate cash to meet its financial obligations (Gray et al., 2006). In this context, we expect a positive relationship between credit rating and profitability. According to Bouzouita and Young (1998), "profitability reflects the ability of management to maintain strong operation and adequate pricing". In this sense, companies that experience a sustained increase in the level of their surplus are more likely to receive a better rating. Adams et al. (2003) point out that examination of profitability enables financial analysts and industry regulators to assess a firm's ability to invest annual surpluses efficiently in order to generate new business. Furthermore, meas- ures of profitability also provide insights into management's ability to control expenses effectively and to set competitive rates of premium. Measuring profitability provides an indication of the extent to which firms can invest money in an efficient way. The greater the profitability, the lower the insolvency risk and, consequently, the better the firms' credit rating (Brotman, 1989, Bouzouita and Young, 1998; Adams et al., 2003; and Gray et al., 2006).

1.2.3. Liquidity. According to Carson and Scoot (1997) and Bouzouita \& Young, (1998), a high degree of liquidity enables the insurer to meet unexpected needs for cash without having to sell assets at a discounted value". In general, higher liquidity indicates that a firm has a better ability to cover short-term liabilities with current assets that can be transformed into money much faster than long-term assets (Roje, 2005). Empirical evidence shows that liquidity is an important factor in the corporate decision to obtain a credit rating (Adams et al., 2003).

1.2.4. Size. As observed in business practice, large companies have easier access to credit and are considered important for the economy of a country as a whole. Thus, they tend to receive aid from the government, as they are too big to fail. Moreover, Bouzouita and Young (1998, p. 27) argue that "large companies are better able to sustain unfavorable changes in economic conditions". Bhojraj and Sengupta (2003) agree when they mention that large companies have high rating because of their low market risks. Kim and $\mathrm{Gu}$ (2004) found a positive relationship between size and rating. According to these authors, this is due to their better ability to minimize the impact of economic, social, and political changes. According to Blum, Lim and Mackinlay (1998), larger firms tend to be more diversified and have easier access to capital markets, so their ability to face financial difficulties is high as a result they are more likely to receive a higher credit rating. This is consistent with Bouzouita and Young (1998), who suggest that larger firms depend on economies of scale in their operations and have managerial expertise that enables the firm to overcome financial difficulties.

1.2.5. Growth. More growth opportunities mean more future cash flow, less future uncertainty and less insolvency risk. According to Pottier and Sommer (1999) and Adams et al. (2003), higher growth opportunities are associated with higher credit rating. In the same view, Bouzouita and Young (1998, p. 26) claim that "firms who experience a sustained increase in the level of their surplus are more likely to receive a better rating".

1.2.6. Interest coverage. According to Blum, Lim and Mackinlay (1998) and Gray et al. (2006), the higher the interest coverage ratio, the higher the credit rating. Higher interest coverage means that firms are 
able to meet their financial obligations and this will be associated with lower risk. The interest coverage ratios attempt to capture a company's ability to generate cash flow to pay interest expenses (Murcia et al. 2014). Therefore, we expected financial coverage to be positively correlated to a credit rating. According to Gray et al. (2006), credit rating tends to be highly sensitive to a firm's interest coverage ratio; thus, firms with higher coverage ratios are likely to have higher credit rating. For Ashbaugh-Skaife, Collins and LaFond (2006), as a company's operating cash flow declines, the default risk increases, leading to lower credit rating. Thus, a low level of financial coverage may represent high risk.

1.2.7. Country rating. Borensztein, Cowan, and Valenzuela (2006) point out that there is a positive relationship between sovereign rating and bank rating. Banks are highly leveraged than any other non-financial corporations, so they are more sensitive to the fluctuations in the macro conditions related to sovereign defaults, also, banks are greatly affected by sovereign defaults, especially when part of the bank portfolios are public liabilities.

1.3. Capital structure, credit rating and bank performance. Most empirical studies that analyze the relationship between capital structure and firm performance have been done for individual countries, thus, limiting the generalizability of the results of such studies. The purpose for this study is to fill the gap related to capital structure and bank performance in the MENA area. Some studies have concluded that the relationship between capital structure and firm performance is both positive and negative (Tian et al., 2007; Tsangyaa et al., 2009; Saeedi and Mahmoodi, 2011; Abor, 2005; Oke and Afolabi, 2008), others concluded that the relationship is negative (Narendar et al., 2007; Pratheepkanth, 2011; Shah, et al., 2011; Onaolapo and Kajola, 2010). Yet, other studies have documented a positive relationship (Shoaib and Siddiqui, 2011; Aman, 2011; Chowdhury and Chowdhury, 2010; Omorogie and Erah, 2010; Akintoye, 2008). With these mixed and conflicting results, the quest for examining the relationship between capital structure and firm performance has remained a puzzle and empirical study continues.

\section{Methodology}

2.1. Study hypotheses. This study tests the following hypotheses:

H1: There is a positive association between capital structure and profitability.

H2: There is a positive association between capital structure and tangibility.

H3: There is a positive association between capital structure and non-debt tax shield.

H4: There is a positive association between capital structure and liquidity.

H5: There is a positive association between capital structure and bank size.

H6: There is a positive association between capital structure and inflation.

H7: There is a positive association between capital structure and operating risk.

H8: There is a positive association between capital structure and growth opportunities.

H9: There is a negative association between leverage and credit rating.

H10: There is a positive association between profitability and credit rating.

H11: There is a positive association between liquidity and credit rating.

H12: There is a positive association between bank size and credit rating.

H13: There is a positive association between growth rates and credit rating.

H14: There is a positive association between interest coverage and credit rating.

H15: There is a positive association between country rating and credit rating.

H16: There is a significant relationship between capital structure, credit rating and bank performance.

2.2. Models. 2.2.1. The determinants of capital structure decisions. The study aims to examine the main determinants of capital structure taking into account the effect of credit rating. To do this, two models are set. The first one includes the most commonly used variables in determining the leverage. The second includes the variables included in model (1) in addition to credit rating to test the impact of credit rating on the bank leverage.

Model (1):

$D E B T=\alpha+\beta_{1} P R O F+\beta_{2} T A N G+\beta_{3} L I Q+\beta_{4} N D T S+\beta_{5} I N F+\beta_{6} R I S K+\beta_{7} S I Z E+\beta_{8} G R O+\varepsilon$.

Model (2):

$D E B T=\alpha+\beta_{1} P R O F+\beta_{2} T A N G+\beta_{3} L I Q+\beta_{4} N D T S+\beta_{5} I N F+\beta_{6} R I S K+\beta_{7} S I Z E+\beta_{8} G R O+\beta_{9} C R+\varepsilon$.

Where $D E B T$ is a measure of capital structure and is measured by the ratio of total debt to total assets, $P R O F$ is the profitability and measured by return on equity, TANG is the tangibility and is measured by the ratio of fixed assets to total assets, NDTS is nondebt tax shield and is measured by dividing depreciation on total assets, LIQ denotes to liquidity and is measured by the ratio of net loans to total assets, 
INF is inflation rate, RISK is measured by the variance coefficient of operating income, SIZE is the natural logarithm of total assets, $G R O$ is growth and is measured by percentage change in total assets, $C R$ is credit rating and is a dummy variable (equal to 1 ) for banks with credit rating and (equal to 0 ) for banks without any credit rating. The dependent variable used in this paper is the debt ratio $(D / T A)$. According to the agency, cost theory of capital structure, high leverage are expected to reduce agency cost, reduce inefficiency and, eventually, lead to improvements in firm's performance. Berger (2002) argues that an increase in the leverage ratio should result in lower agency costs outside equity and improve firm's performance, all other things being equal. From the analysis above, an inverse relationship is expected to be between leverage and firm performance.

2.2.2. The Determinants of credit rating. The study also investigates the determinants of credit rating using a logistic regression model, where the dependent variable takes 1 for all banks with credit rating and 0 , otherwise. A binary logistic regression is modelled as follows:

$C R=\alpha+\beta_{1} L E V+\beta_{2} P R O F+\beta_{3} L I Q+\beta_{4} S I Z E+$

$+\beta_{5} G R O+\beta_{6} C O V+\beta_{7} C O R A+\varepsilon$,

where $C R$ is credit rating and is a dummy variable (equal to 1 ) for banks with credit rating and (equal to 0 ) for banks without any credit rating, $\mathrm{COV}$ is the interest coverage and is measured by the ratio of earnings before interest and tax to interest expense, and CORA is the country rating and is measured by the foreign currency long-term rating and is a categorical variable that is equal to 1 for banks with $\mathrm{A}$, 2 for $\mathrm{BBB}, 3$ for $\mathrm{BB}$ and 4 for $\mathrm{B}$ rating.

2.2.3. The impact of credit rating and capital structure decision on banks' profitability. The effect of capital structure decision and credit rating on the performance of the bank is examined in this study.
The return on asset (ROA) as a measure of profitability is regressed against the ratio of total debt to total assets as a measure of leverage. The credit rating is added as a dummy variable (takes 1 ) for banks with credit rating and (takes zero) for banks without any credit rating. The bank size is used as a control variable. The following model is used:

$P R O F=\alpha+\beta_{1} L E V+\beta_{2} C R+\beta_{3} S I Z E+\varepsilon$.

2.2.4. Measurement of capital structure. In this study, capital structure is measured by the ratio of total debt divided by total assets. Chittenden et al. (1996) argue that the use of total debt will make it difficult to identify exactly the effect of total debt on leverage, where long-term debt and short-term debt will have different impacts on some independent variables such as the size, collateral asset and growth opportunities. As a result of data limitation, the study will measure debt by using book values rather than market values. It is supposed to be better to use the market values than the book values. But most of the empirical studies use the book value, where it is found that there is a highly correlation between the book value of debt and the market value of debt, and the difference will be very small. Therefore, the book value of debt can be used instead of the market value.

\section{Empirical results}

3.1. Descriptive statistics. Table 2 presents the descriptive statistics of the study variables. On average, banks have a debt ratio of about $52.2 \%$. The debt ratio variation across the sample was large, ranging from a maximum $68.13 \%$ and a minimum of $6.88 \%$. With regards to the explanatory variables, the average size is $14.03 \%$ with median of $11.95 \%$ and standard deviation of 1.49 . The correlation results (not enclosed) show that the multicollinearity problem does not exist as the highest correlation coefficient is -0.298 between size and tangibility.

Table 2. The descriptive statistics

\begin{tabular}{|l|c|c|c|c|c|}
\hline \multicolumn{1}{|c|}{ Variable } & Max & Min & Mean & Median & St. deviation \\
\hline Leverage & 68.13 & 6.88 & 52.19 & 58.65 & 14.71 \\
\hline Profitability & 18.35 & 0 & 2.55 & 1.89 & 3.65 \\
\hline Tangibility & 0.118 & 0 & .0144 & 0.02 & 0.01 \\
\hline Non-debt tax shield & 0.936 & 0 & 0.075 & 0 & 0 \\
\hline Liquidity & 74.83 & 0 & 31.41 & 30.2 & 12.36 \\
\hline Inflation & 13.55 & 0.45 & 3.88 & 3.49 & 2.57 \\
\hline Risk & 1.86 & 0.08 & 0.188 & 0.15 & 0.12 \\
\hline Size & 19.29 & 10.02 & 14.03 & 11.95 & 1.49 \\
\hline Growth opportunities & 93.36 & -40.39 & 23.45 & 12.86 & 11.42 \\
\hline
\end{tabular}

Note: Leverage is measured by the ratio of total debt to total assets, Profitability is measured by return on equity, Tangibility is measured by the ratio of fixed assets to total assets, NDTS is non-debt tax shield and is measured by dividing depreciation on total assets, Liquidity is measured by the ratio of net loans to total assets, Inflation: inflation rate, Risk is measured by the variance coefficient of operating income, Size is the natural logarithm of total assets, Growth opportunities are measured by percentage change in total assets. 
3.2. Regression results. The results from Table 3 indicate a significant positive relationship at $1 \%$ between credit rating and leverage. The effect of adding credit rating into the model is clear, as the adjusted $\mathrm{R}$ square increased from 0.575 to 0.628 indicating that adding credit rating to the model adds more explanatory power. Table 3 shows that profitability has a significant negative relation between the profitability and the gearing. This result is consistent with the pecking order theory and, also, matches with the empirical results of Titman and Wessels (1998), Rajan and Zingales (1995), Booth et al. (2001) and Bevan and Danbolt (2002), but it contradicts with the tradeoff theory and the empirical results of Bowen et al. (1982), Givoly et al. (1992) where profitable firms should use more debt to benefit from the tax shield. Table 3 also shows that the relationship between tangibility and leverage is negative and statistically significant. This matches with the results of Booth et al. (2001) and Nivorozhkin (2002) who investigate the determinants of capital structure on developing countries and find that tangibility is inversely related to debt. The result differs from the predicted sign of the pecking order theory and tradeoff theory and the empirical evidence that supports the positive relation between tangibility and gearing such as Titman and Wesels (1988), Rajan and Zingales (1995), Kremp et al. (1999), and Frank and Goyal (2003). From Table 3, it is found that tangibility has the biggest coefficient indicating the importance of tangibility in the capital structure decision and the degree to which capital structure is influenced by tangibility. The result of non-debt tax shield (NDTS) matches with the tradeoff theory indicating that there is a significant positive relation between the NDTS and leverage. This result, also, is in accordance with the empirical results of Haugen and Senbet (1986) and Mackie-Mason (1990). Liquidity is expected to have a negative relationship with leverage. But the result in Table 3 indicates that liquidity has an insignificant positive correlation with the debt ratio. According to the pecking order theory, more liquidity results in lower leverage. Inflation rate: inflation rate measured by consumer price index (CPI) has a significant positive relation with debt ratio as a result of reducing the cost of debt during the inflationary periods. This is consistent with the results of Homaifar et al. (1994). For operating risk, banks with relatively high operating risk will have incentives to lower their leverage. This significant negative relation matches with the tradeoff theory, since increasing earnings volatility increases the likelihood of financial distress, then, the use of debt will be limited. The result is the same with the result obtained by Titman and Wessels (1988), Kremp et al. (1999), Booth et al. (2001) and Dasilas and Papasyriopoulos (2015).
Table 3. The determinants of capital structure

\begin{tabular}{|c|c|c|}
\hline Variables & $\begin{array}{l}\text { Coefficient (without credit } \\
\text { rating) }\end{array}$ & $\begin{array}{l}\text { Coefficient (with } \\
\text { credit rating) }\end{array}$ \\
\hline Constant & $6.99^{\star \star \star}$ & $7.22^{* \star \star}$ \\
\hline Profitability & $-2.79^{\star \star \star}$ & $-3.26^{\star \star \star}$ \\
\hline Tangibility & $-0.29^{\star \star \star}$ & $-0.349^{*}$ \\
\hline Non-debt tax shield & $3.84^{* *}$ & $4.35^{\star \star *}$ \\
\hline Liquidity & 0.047 & 0.015 \\
\hline Inflation & 0.31 & $0.96^{* *}$ \\
\hline Risk & $-6.93^{* \star \star}$ & $-10.95^{\star \star}$ \\
\hline Size & $-1.22^{*}$ & $-8.89^{\star \star \star}$ \\
\hline Growth & $0.13^{\star \star}$ & $0.085^{\star *}$ \\
\hline Credit rating & & $9.15^{\star \star \star}$ \\
\hline F-value & $24.87^{* * *}$ & $38.55^{\star * *}$ \\
\hline Adjusted R square & 0.575 & 0.628 \\
\hline
\end{tabular}

Note: Leverage is measured by the ratio of total debt to total assets, Profitability is measured by return on equity, Tangibility is measured by the ratio of fixed assets to total assets, NDTS is non-debt tax shield and is measured by dividing depreciation on total assets, Liquidity is measured by the ratio of net loans to total assets, Inflation: inflation rate, Risk is measured by the variance coefficient of operating income, Size is the natural logarithm of total assets, Growth opportunities are measured by percentage change in total assets, and Credit rating is a dummy variable (equal to 1) for banks with CR and (equal to 0 ) for banks without any $\mathrm{CR}$. $* * * 1 \%$; **5\%; *10\%

There is a conflicting evidence regarding the relation between leverage and the size. The result in Table 3 presents a significant negative relation between the size of the bank and leverage. The pecking order theory indicates a negative relation, and the empirical results of Kester (1986), Titman and Wessels (1988), and Kremp et al. (1999) also find the same negative relation. But this contradicts with the positive relation between the size and the debt ratio suggested by the tradeoff theory and supported by the evidence of Rajan and Zingales (1995), Booth et al. (2001), and Bevan and Danbolt (2002). Growth opportunities: the result in Table 3 is consistent with the assumptions of the pecking order theory, where there is a significant positive relation between growth opportunities and the debt ratio. More growing firms will use internally generated funds as a result of growth; those highly growing firms will seek for an external source of finance to be able to finance their growth. The results match with the results of Michaelas et al. (1999), and Bevan and Donbolt (2002), but contradict the tradeoff theory and also the empirical evidence of Titman and Wessels (1988) and Rajan and Zingales (1995). In addition, there is a positive relation between credit rating and leverage and this relation is highly significant at $1 \%$. The coefficient of credit rating is large (9.15) meaning that banks with credit rating will issue debt by $9.15 \%$ more than banks without credit rating can issue. The result is considered a confirmation of the results of Graham and Harvey (2001) who point out that credit rating is the second most important factor after maintenance of financial flexibility in the decision to issue more debt, and Kis- 
gen (2006) who argues that credit rating is very important in the leverage decision.

Table 4 shows that there are only two variables that are significant in determining credit rating, those variables are the size of the bank and foreign currency long-term rating as a measure for country rating. Size: there is a significant positive relationship between the bank size and the probability of the bank to be rated as the bank size increases the likelihood that banks will be rated increases and this is consistent with previous studies of Blum et al. (1998). Country rating: there is a significant positive relation between the country rate and the likelihood that banks will be rated. Any increase in the country rate from one grade to a higher grade will increase the probability of banks located in this country to be rated and this matches with the results of Borensztein et al. (2006).

Table 4. The determinants of credit rating

\begin{tabular}{|l|c|c|}
\hline \multicolumn{1}{|c|}{ Variables } & Coef & Exp (B) \\
\hline Leverage & .085 & 1.088 \\
\hline Profitability & .173 & 1.129 \\
\hline Liquidity & -.028 & .992 \\
\hline Size & $1.398^{\star \star \star}$ & 3.779 \\
\hline Growth opportunities & -.009 & .989 \\
\hline Interest coverage & -.161 & .877 \\
\hline Country rating (1) & $-7.190^{\star \star *}$ & .000 \\
\hline Country rating (2) & $4.723^{\star \star *}$ & 80.465 \\
\hline Country rating (3) & $5.466^{\star \star *}$ & 92.911 \\
\hline Country rating (4) & $2.321^{* \star *}$ & 18.933 \\
\hline
\end{tabular}

Note: Leverage is measured by the ratio of total debt to total assets, Profitability is measured by return on equity, Liquidity is measured by the ratio of net loans to total assets, Size is the natural logarithm of total assets, Growth opportunities are measured by percentage change in total assets, Interest coverage is measured by the ratio of earnings before interest and tax to interest expense, and Country rating is measured by foreign currency long-term rating will be used as a proxy for country rating and is a categorical variable which takes a value of 1 for banks with foreign currency long term rating $\mathrm{A}, 2$ for $\mathrm{BBB}, 3$ for $\mathrm{BB}$ and 4 for $\mathrm{B}$ rating. $* * * 1 \%$.

The results in Table 5 indicate that there is a negative relation between the debt ratio and the banks' profitability and this relationship is significant at $1 \%$ level. In addition, there is a positive relationship between credit rating and the profitability of banks and the result is statistically significant at $1 \%$ level. The size is positively and significantly associated with bank profitability.

Table 5. The relationship between capital structure, credit rating and bank profitability

\begin{tabular}{|l|c|}
\hline & Coefficient \\
\hline Constant & $11.352^{\star \star \star}$ \\
\hline Leverage & $-.838^{\star \star \star}$ \\
\hline Credit rating & $0.627^{\star \star *}$ \\
\hline Size & $0.862^{\star \star \star}$ \\
\hline
\end{tabular}

\begin{tabular}{|l|c|}
\hline F. test & $35.34^{\star \star \star}$ \\
\hline$R^{2}$ & 0.597 \\
\hline
\end{tabular}

Note: Leverage as a proxy for capital structure is measured by total debts to total assets. Credit rating is a dummy variable (equal to 1) for banks with credit rating and (equal to 0 ) for banks without any credit rating. Size is the natural logarithm of total assets, Growth opportunities are measured by percentage change in total assets, $* * * 1 \%$.

\section{Conclusion}

The main purpose of the study is to: 1) examine the impact of credit rating on capital structure decisions of MENA banks, 2) identify the determinants of credit rating, and 3) examine the effect of credit rating and capital structure on banks' profitability. The effect of credit rating is an important determinant besides the traditional determinants that are most commonly used by the academic literature. This has been achieved by regressing capital structure (measured by the ratio of total debt to total assets) against: profitability, tangibility (the ratio of fixed assets to total assets), size of the bank (natural logarithm of total assets), non-debt tax shield, liquidity of the bank (the ratio of net loans to total assets), inflation rate, operating risk (variance coefficient of operating income), growth opportunities (percentage change in total assets), and, finally, credit rating (a dummy variable equals to 1 for banks with credit rating and zero, otherwise). Capital structure is found to be significantly positively correlated with non-debt tax shield, inflation rate, growth opportunities, and credit rating, and significantly negatively correlated with profitability, tangibility, operating risk, and size. The findings of this study support the hypothesis of credit rating as a determinant in firms' choice of capital structure. Finally, the study found that banks' profitability significantly and negatively correlated with the debt ratio, and positively correlated with credit rating, but this correlation is not significant.

This study has an implication on investors in their decisions to invest in the banking industry. It is also helpful for policy makers to understand how bank's capital structure behaves so they could take into consideration when issuing new regulations such as Basel III. On the other hand, this study has some limitations.

One of these limitations is data availability as credit rating is available only for one year, so future research can generate better results if they use the rating data of different years. A risk with the present study is also at there the sample may not be totally homogenous; differences in jurisdiction between the countries may affect firms' capital structure decisions differently. Future research can study whether the influence of credit rating in the capital structure choice of firms varies for different industries. Another possibility is to increase the number of firms in the sample, including firms from developing and developed countries. 
Another extension of the present study would be to employ the same empirical set-up on MENA banks but using the corporate credit rating of another CRA (e.g., Moody's) and see whether there are any differences between the impacts of rating considerations between the different CRAs. Finally, the effect of 2008 financial crisis on capital structure and credit rating should be tested too.

\section{References}

1. Abor, J. (2005). The effect of capital structure on firm performance: an empirical analysis of listed firms in Ghana, Journal of Risk Finance, 2, pp. 438-447.

2. Adams, M., Burton, B. and Hardwick, P. (2003). The determinants of credit rating in the united kingdom insurance industry, Journal of Business Finance and Accounting, 30 (3-4), pp. 539-572.

3. Adeyemi, S.B. \& Oboh, C.S. (2011). Perceived relationship between corporate capital structure and firm value in Nigeria, International Journal of Business and Social Science, 2, pp. 1-2.

4. Akintoye, I.R. (2008). Effect of capital structure on firms' performance: the Nigerian experience, European Journal of Economics, Finance and Administrative Sciences, (10), pp. 233-243.

5. Al-Sakran, S.A. (2001). Leverage determinants in the absence of corporate tax system: the case of non-financial publicly traded corporations in Saudi Arabia, Managerial Finance, (27), pp. 58-86.

6. Aman, S. (2011).Ownership structure and corporate performance: evidence from India, International Journal of Humanities and Social Science, 1 (1), pp. 23-29.

7. Asgharian, H. (2005). Reformation of the credit rating industry-is there a need? Master Thesis, Institution of Business Studies.

8. Ashbaugh-Skaife, H., Collins, D. \& LaFond, R. (2006). The effects of corporate governance on firms' credit rating, Journal of Accounting and Economics, 42 (1), pp. 203-243.

9. Barclay, M.J. and Smith, C.W. (1996). On financial architecture: leverage, maturity and priority, Journal of Applied Corporate Finance, 8 (4), pp. 4-17.

10. Bathala, C., Moon, K. and Rao, R. (1994). Managerial ownership, debt policy and the impact of institutional holdings: An agency perspective, Financial Management, 23 (3), pp. 38-50.

11. Bennett, M. and Donnelly, R. (1993). The determinants of capital structure: some UK evidence, British Accounting Review, 25, pp. 43-59.

12. Bevan, A.A. and Danbolt, J. (2002). Capital structure and its determinants in the United Kingdom: A decompositional analysis, Applied Financial Economics, 12 (3), pp. 159-170.

13. Bevan, A.A. and Danbolt, J. (2004). Testing for inconsistencies in the estimation of UK capital structure determinants, Applied Financial Economics, 14 (1), pp. 55-66.

14. Bhojraj, S. and Sengupta, P. (2003). Effect of corporate governance on bond rating and yields: the role of institutional investors and outside directors, The Journal of Business, 76 (3), pp. 455-476.

15. Blume, M., Lim, F. and Mackinlay, C. (1998). The declining credit quality of U.S. corporate debt: myth or reality? Journal of Finance, 53 (4), pp. 1389-1413.

16. Boot, A., Milbourn, T. and Schmeits, A. (2003). Credit rating as coordination mechanisms, working paper, Washington University, St.Louis.

17. Booth, L., Aivazian, V., Demirguc-Kunt, A. and Maksimovic, V. (2001). Capital structure in developing countries, Journal of Finance, 56 (1), pp. 87-130.

18. Bouzouita, R. and Young, A.J. (1998). A probit analysis of best rating, Journal of Insurance Issues, 21, pp. 23-34.

19. Bowen, R.M., Daley, L.E. and Huber, C. (1982). Leverage measures and industrial classification: review and additional evidence, Financial Management, 11 (4), p. 10.

20. Bradley, M., Jarrell, G. and Kim, E.H. (1984). On the existence of and optimal capital structure: theory and evidence, Journal of Finance, 39 (3), pp. 857-878.

21. Brothman, B.A. (1989). Reliability of best's insurer rating using financial information published in the annual report, Journal of Insurance Issues and Practices, 12, pp. 58-70.

22. Cantor, R. and Packer, F. (1997). Differences of opinion and selection bias in the credit rating industry, Journal of Banking and Finance, 21 (10), pp. 1395-1417.

23. Casser, G. and Holmes, S. (2003). Capital structure and financing of SMEs: Australian evidence, Accounting and Finance, 43 (2), pp. 123-147.

24. Champsaur, A. (2005). The regulation of credit rating agencies in the U.S. and the E.U.- recent initiatives and proposals, Seminar in International Finance, LL.M. paper, Harvard Law School.

25. Chen, J.J. (2004). Determinants of capital structure of Chinese-listed companies, Journal of Business Research, 57, pp. 1341-1351.

26. Chittenden, F., Hall, G. and Hutchinson, P. (1996). Small firm growth, access to capital markets and financial structure: review of issues and an empirical investigation, Small Business Economics, 8 (1), pp. 59-67.

27. Chowdhury, A. and Chowdhury, P.S. (2010). Impact of capital structure on firm's value: evidence from Bangladesh, Peer reviewed and open access journal, 3 (3), pp. 111-115.

28. Chung, K.H. (1993). Assets characteristics and corporate debt policy: an empirical test, Journal of Business Finance and Accounting, 20 (1), pp. 83-98. 
29. Dammon, R.M. and Senbet, L.W. (1988). The effect of taxes and depreciation on corporate investment and financial leverage, Journal of Finance, 43, pp. 357-373.

30. Dasilas, A. and Papasyriopoulos, N. (2015). Corporate governance, credit rating and the capital structure of Greek SME and large listed firms, Small Business Economics, 45, pp. 215-244.

31. DeAngelo, H. and Masulis, R.W. (1980). Optimal capital structure under corporate and personal taxes, Journal of Financial Economics, 8 (1), pp. 3-29.

32. DeJong, A. (1999). An empirical analysis of capital structure decisions in Dutch firms. PhD. dissertation. Center, Tilburg University.

33. Deesomsak, R., Paudyal, K. and Pescetto, G. (2004). The determinants of capital structure: evidence from the Asia pacific region, Journal of Multinational Finance Management, 14 (4), pp. 387-405.

34. Degryse, H., De Goeij, P. and Kappert, P. (2012). The impact of firm and industry characteristics on small firms' capital structure, Small Business Economics, 38 (4), pp. 431-447.

35. Eldomiaty, T.I. (2007). Determinants of Corporate Capital Structure: Evidence from an Emerging Economy, International Journal of Commerce and Management, 17 (1-2), pp. 25-43.

36. Fama, E.F. and French, K.R. (2000). Testing tradeoff and pecking order predictions about dividends and debt. The center for Research in Security prices, Working Paper NO. 506.

37. Ferri, M.G. and Jones, W.H. (1979). Determinant of financial structure: a new methodological approach, Journal of Finance, 34 (3), 631-644.

38. Frank, M. and Goyal. (2003). Testing the pecking order theory of capital structure, Journal of Financial Economics, 67 (2), pp. 217-248.

39. Frost, C.A. (2006). Credit rating agencies in capital markets: a review of research evidence on selected criticisms of agencies, Journal of Accounting, Auditing and Finance, pp. 469-492.

40. Gaud, P., Jani, E., Hoesli, M. and Bender, A. (2005). The capital structure of Swiss companies: an empirical analysis using dynamic panel data, European Financial Management, 11 (1), pp. 51-69.

41. Givoly, D., Hayn, C., Ofer, R. and Sarig, O. (1992). Taxes and capital structure: evidence from firms' response to the tax reform act of 1986, Review of Financial Studies, 5 (2), pp. 331-355.

42. Graham, J.R. and Harvey, C.R. (2001). The theory and practice of corporate finance: evidence from the field, Journal of Financial Economics, 60, pp. 187-243.

43. Gray, S., Mirkovic, A. and Ragunathan, V. (2006). The determinants of credit rating: Australian evidence, Australian Journal of Management, 31 (2), pp. 333-354.

44. Gropp, R. \& Heider, F. (2010). The Determinants of Bank Capital Structure, Review of Finance, 14, pp. 587-622.

45. Haugen, R. and Senbet, L. (1986). Corporate finance and taxes: a review, Financial Management, 15 (3), pp. 5-21.

46. Homaifar, G., Zietz, J. and Benkato, O. (1994). An empirical model of capital structure: some new evidence, Journal of Business Finance Accounting, 21 (1), pp. 1-14.

47. Jaffe, J.F. (1978). A note on taxation and investment, Journal of Finance, 33 (5), pp. 1439-1445.

48. Jiraporn, P., \& Gleason, K. (2007). Capital structure, shareholder rights and corporate Governance, Journal of Financial Research, 30 (1), pp. 21-33.

49. Jordan, J., Lowe, J. and Taylor, P. (1998). Strategy and financial management in UK small firms, Journal of Business and Accounting, 25 (1), pp. 1-27.

50. Jucá, M.N., De Sousa, A.F. and Fishlow, A. (2012). Capital Structure Determinants of North American Banks and the Compensation Executive Program- An Empirical Study on the Actual Systemic Crisis, International Journal of Business and Management, 7, p. 13.

51. Kemper, K.J. (2011). Do credit rating really affect capital structure? Oklahoma State University.

52. Kester, C.W. (1986). Capital and ownership structure: a comparison of United States and Japanese manufacturing corporations, Financial Management, 15 (1), pp. 5-16.

53. Kim, H., and Gu, Z. (2004). Financial determinants of corporate bond rating: an examination of hotel and casino firms, Journal of Hospitality \& Tourism Research, 28 (1), pp. 95-108.

54. Kisgen, D.J. (2006) Credit rating and capital structure, Journal of Finance, 61 (3), pp. 1035-1072.

55. Kisgen, D.J. (2009). Do Firms Target Credit Rating or Leverage Levels? Journal of Financial and Quantitative Analysis, 44, pp. 1323-1344.

56. Kremp, E. Stoss, E., and Gerdesmeier, D. (1999). Estimation of a debt function: evidence from French and German firm panel data. In Sauvé, A., Scheuer, M (ed.) Corporate finance in Germany and France A joint research project of Deutsche Bundesbank and die Banque de France, SSRN working paper.

57. Kronwald, C. (2009). Credit rating and the impact on capital structure. Who knows what: Information on capital markets. University of Hohenheim.

58. Lopez-Gracia, J. and Sogorb-Mira, F. (2008). Testing trade-off and pecking order theories financing SMEs, Small Business Economics, 31 (2), pp. 117-136.

59. MacKie-Mason, J.K. (1990). Do taxes affect corporate financing decisions? Journal of Finance, 45 (5), pp. 1471-1493.

60. Marsh, P. (1982). The choice between equity and debt: an empirical study, Journal of Finance, 37 (1), pp. 121-144.

61. Mateev, M., Poutziouris, P., and Ivanov, K. (2013). On the determinant of SME capital structure in Central and Eastern Europe. A dynamic panel analysis, Research in International Business and Finance, 27 (1), pp. 28-51. 
62. Michaelas, N., Chittenden, F. and Poutziouris, P. (1999). Financial policy and capital structure choice in U.K. SMEs: empirical evidence from company panel data, Small Business Economics, 12 (2), pp. 113-130.

63. Michelsen, M. \& Klein, C. (2011). The relevance of external credit rating in the capital structure decision-making process. University of Hohenheim.

64. Modigliani, F. (1982). Debt, dividend policy, taxes, inflation and market valuation, Journal of Finance, 37 (2), pp. 255-273.

65. Modigliani, F. and Miller, M.H. (1963). Corporate income taxes and the cost of capital-a correction, American Economic Review, 53 (3), pp. 433-443.

66. Murcia, F.C. de S., Murcia, F.D., Rover, S. and Borba, J.A. (2014). The Determinants of Credit Rating: Brazilian Evidence, BAR, Rio de Janeiro, 11 (2), pp. 188-209.

67. Myers, S.C. (1999). Testing static trade-off against pecking order models of capital structure, Journal of Financial Economics, 51, 219-244.

68. Myers, S.C. (1977). Determinants of corporate borrowing, Journal of Financial Economics, 5, pp. 147-175.

69. Myers, S.C. (1984). The capital structure puzzle, Journal of Finance, 39, pp. 575-592.

70. Myers, S.C. and Majluf, N.S. (1984). Corporate financing and investment decisions when firms have information that investors do not have, Journal of Financial Economics, 13, pp. 104-119.

71. Narendar, V.R., Khamis, H.M. and Lateef, A.S. (2007). Capital structure and financial performance: evidence from Oman, Indian Journal of Economics and Business, 2, pp. 57-65.

72. Nguyen, T.D. and Ramachandran, N. (2006). Capital structure in small and medium-sized enterprises-the case of Vietnam, ASEAN Economic Bulletin, 23 (2), pp. 192-211.

73. Nikolaos, E., Dimitrios, V. \& Zoe, V.-N. (2007). How firm characteristics affect capital structure: an empirical study, Managerial Finance, 33, pp. 321-331.

74. Nivorozhkin, E. (2002). Capital structures in emerging stock markets: the case of Hungary, The Developing Economies, 40 (2), pp. 166-187.

75. Ojah, K. and Manrique, J. (2005). Determinants of corporate debt structure in a privately dominated debt market: a study of Spanish capital market, Applied Financial Economics, 15 (7), pp. 455-468.

76. Oke, O.O. and Afolabi, B. (2008). Capital structure and industrial performance in Nigeria, Journal of Social Science, 4 (1), pp. 13-21.

77. Omorogie, A.N. and Erah, D.O. (2010). Capital structure and corporate performance in Nigeria: an empirical investigation, AAU Journal of Management Sciences, 1 (1), pp. 43-52.

78. Onaolapo, A. and Sunday, K. (2010). Capital structure and firm performance: Evidence from Nigeria, European Journal of Economics, Finance and Administrative Sciences.

79. Ozkan, A. (2000). An empirical analysis of corporate debt maturity structure. European Financial Management, 6 (2), pp. 197-212.

80. Ozkan, A. (2001). Determinants of capital structure and adjustment to long run target: Evidence from UK company panel data, Journal of Business Finance \& Accounting, 28, pp. 175-198.

81. Ozkan, A. (2001). Determinants of Capital Structure and Adjustment to Long Run Target: Evidence From UK Company Panel Data, Journal of Business Finance \& Accounting, 28, pp. 175-198.

82. Palata, M. (2003). Capital structure-theory and the Czech practice. Diploma thesis, Charles University Prague, Faculty of Social Sciences, Institute of Economic Studies.

83. Pottier, S.W., Sommer, D.W. (1999). Property-liability insurer financial strength rating: differences across rating agencies, Journal of Risk and Insurance, 66 (4), pp. 621-642.

84. Pratheepkanth, P. (2011). Capital structure and financial performance: evidence from selected business companies in Colombo Stock Exchange, Sri Lanka, Journal of Arts, Science and Commerce, 2 (2), pp. 171-173.

85. Rajan, R.G. and Zingales, L. (1995). What do we know about capital structure? Some evidence from international data, Journal of Finance, 50 (5), pp. 1421-460.

86. Roje, G. (2005). The role of accounting determinants in predicting long term credit rating. Proceedings of the European Accounting Association Congress, Gotheborg, Sweden, 28.

87. Saeedi, A. and Mahmoodi, I. (2011). Capital structure and firm performance: evidence from Iranian Companies, International Research Journal and Economics, 70, pp. 20-26.

88. Sbeti, W.M. (2010). The Determinants of Capital Structure: evidence from the GCC Countries, International Research Journal of Finance and Economics, pp. 54-79.

89. Servaes, H. and Tufano, P. (2006). The Theory and Practice of Corporate Capital Structure, working paper, Deutsche Bank.

90. Shah S.Z., Butt, S.A. and Saeed, M.M. (2011). Ownership structure and performance of firms: empirical evidence from an emerging market, African Journal of Business Management, 5 (2), pp. 515-519.

91. Shen, C.H., Huang, Y.L. \& Hasan, I. (2012). Asymmetric benchmarking in bank credit rating, Journal of International Financial Markets Institutions and Money, 22 (1), pp. 171-193.

92. Shiu, Y. \& Chiang, C. (2008). Determinants of financial strength rating: evidence from the Lloyd's Market. Retrieved from http://portal.business.colostate.edu/projects/ARIA/Shared\%20Documents/2a_Shiu_Determinant s\%20of\%20Financial\%20Strength\%20Rating.pdf.

93. Shoiab, M.M. (2011). Impact of capital structure on firm`s financial performance: evidence from Pakistan, 17 (5), pp. 56-101. 
94. Sogorb-Mira, F. and Shyam-Sunder, L. (2005). How SME uniquneness affects capital structure: Evidence from a 1994-1998 Spanish data panel, Small Business Economics, 25 (5), pp. 447-457.

95. Tian, G.G. and Zeitun, R. (2007). Capital structure and corporate performance: evidence from Jordan, Australian Accounting, Business and Financial Journal, 1 (4), pp. 40-53.

96. Titman, S. (1984). The effect of capital structure on a firm's liquidation decision, Journal of Financial Economics, 13, pp. 137-151.

97. Titman, S. and Wessels, R. (1988). The determinants of capital structure choice, Journal of Finance, 34 (1), pp. 1-19.

98. Toy, N., Stonehill, A., Remmers, L., Wright, R. and Beekhuisen, T. (1974). A comparative international study of growth, profitability and risk as determinants of corporate debt ratios in the manufacturing sector, Journal of Financial and Qualitative Analysis, 19 (5), pp. 875-886.

99. Tsangyaa C., Kuei-Chiu, L., Yao-Men, Y. and Chia-Hao, L. (2009). Does capital structure affect operating performances of credit cooperatives in Taiwan? Application of panel threshold method, International Research Journal of Finance and Economics, 32, pp. 18-21.

100. Van Roy, P. (2006). Is there a difference between solicited and unsolicited bank rating and if so, why? Working Paper Research No. 79, National Bank of Belgium.

101. Wald, J. (1999). How firm characteristics affect capital structure: An international comparison, Journal of Financial Research, 22 (2), pp. 161-187.

102. Walsh, E.J., and Ryan, J. (1997). Agency and tax explanations of security issuance decisions, Journal of Business Finance and Accounting, 24 (7-8), pp. 943-961. 